\title{
Capacity Building for Lifelong Learning: A Study of Practitioners' Perceptions on Information Literacy Framework
}

\author{
Sandy C. LI \\ Department of Education Studies, Hong Kong Baptist University \\ Kowloon Tong, Kowloon, Hong Kong SAR, China \\ e-mail: sandyli@hkbu.edu.hk

\section{Siu Cheung KONG} \\ Department of Mathematics, Science, Social Sciences \& Technology, \\ The Hong Kong Institute of Education \\ Tai Po, NT, Hong Kong SAR, China \\ e-mail: sckong@ied.edu.hk
}

\section{Fong Lok LEE}

Department of Curriculum \& Instruction, The Chinese University of Hong Kong Shatin, NT, Hong Kong SAR, China

e-mail:fllee@cuhk.edu.hk

\section{James HENRI}

CITE, The University of Hong Kong

Pofulam Road, Hong Kong SAR, China

e-mail:jhenri@cuhk.edu.hk

Received: May 2006

\begin{abstract}
Information literacy (IL) has spawned a proliferation of studies in the past two decades. Information literacy is deemed pivotal to the pursuit of both personal empowerment and the economic development of a society. Most of the contemporary interpretations of information literacy are inextricably intertwined with lifelong learning. In this paper, we will (1) examine the commonalities exhibited among a variety of information literacy frameworks developed in different regions; and to deepen our understanding of school principals' and teachers' perceptions on information literacy framework and its role in learning. The research findings indicate that the practitioners share the view that IL should embrace learning outcomes of the four dimensions of learning: cognitive, meta-cognitive, affective and socio-cultural. Results of this study indicate that the traditional notion of information literacy is inadequate to address the learning needs in the 21 st century and a spiral approach to developing students' information literacy is deemed necessary.
\end{abstract}

Key words: information literacy, capacity building, standards and indicators. 


\section{Introduction}

The ongoing, unprecedented growth of information and communication technology, coupled with the globalization of the economy, has created a huge challenge for education. The pursuit of information literacy in education has become widespread with the extensive pervasiveness of global networks. Information literacy education is thus seen as a way to address a growing awareness and demand for preparing students to effectively participate in the emerging global knowledge economy. Bates (2000) contend that, in order to struggle against social exclusion and to maintain competitiveness in a global economy, education must go beyond the framework of initial schooling in order to prepare and support citizens for life-long learning (Curriculum Development Council, 2001). Parallel to the current education reform implemented in Hong Kong, the information literacy is therefore expected to provide a framework which empowers learners to engage critically in information processing and inquiry learning, to become more self-directed, and to assume greater autonomy and social responsibility over their own learning.

Information literacy has spawned a proliferation of studies in the past two decades. The notion of information literacy, emerging with the advent of information and communication technologies, has been shaping the way in which people perceive, process, use and create information. Most of the contemporary interpretations of information literacy are inextricably intertwined with lifelong learning (O'Sullivan, 2002). Information literacy is deemed pivotal to the pursuit of both personal empowerment and the economic development of a society. It is recognised as a kind of "new economy" (O'Sullivan, 2002) and includes lifelong learning skills that are essential for people to cope with the rapidly evolving changes in the era of information age. The World Summit on the Information Society in 2003 stated that "each person should have the opportunity to acquire the necessary skills and knowledge in order to understand, participate actively in, and benefit fully from, the Information Society and the knowledge economy" (World Summit on the Information Society, 2003, para. 29).

In 1998, the Hong Kong Special Administrative Region Government heralded the first IT in education policy, "Information Technology for Learning in a New Era: Five-year Strategy - 1998/99 to 2002/3", signifying her commitment to transforming school education from a largely teacher-centred approach to a more student-centred approach. Riding on what have been achieved, the Education and Manpower Bureau (EMB) of the Hong Kong Special Administrative Region Government issued the second policy document entitled "Empowering Learning and Teaching with Information Technology" in July 2004 (Education and Manpower Bureau, 2004). While the five-year strategy emphasizes the provision of the necessary IT infrastructure for IT in education to launch, one of the goals of IT in education, as espoused in the new strategy, is to empower students to acquire the necessary skills, knowledge and attitudes for lifelong learning and problem solving in the fast-changing information era (Curriculum Development Council, 2000; Education and Manpower Bureau, 1998; Education and Manpower Bureau, 2004; Education and Manpower Bureau, 2005). In this respect, it is thus necessary for both the Government and the practitioners to conceptualize the notion of information literacy and to develop 
an overarching framework to guide the development in curriculum. It is anticipated that the information literacy framework will help teachers to define clear learning outcomes and facilitate students to develop in them the capacity for lifelong learning.

\section{Theoretical Underpinnings}

Despite its widespread use in literature, the traditional way of conceptualizing information literacy solely as either information retrieval skills or IT skills is deemed inadequate to encompass the visions of education in the 21 st century (Menou, 2002). Information literacy is a process of turning information into meaning, understanding, and new ideas (Sanford, 2000). This process would require students to understand the rationale behind using information as well as actually knowing the exact procedures of conducting the information search. Students need to 'know-how', but more importantly, they must first 'know-why'. Hence, being information literate would contribute towards personal empowerment through the learning to learn.

The emerging digital culture coupled with the trends in economic globalization and the quest for a knowledge-based society have been creating tremendous momentum to drive the development and infusion of information literacy in education and all spheres of political, economical and social life of the twenty-first century. In this regard, we argue that information literacy should be framed in a way to empower students to develop in them the capacity for lifelong learning, and to assume greater autonomy and social responsibilities over their learning. The notion of information literacy should be broadened to embrace a wider spectrum of learning outcomes manifested in different dimensions of learning in the information age.

\section{Research Methodology}

The purpose of this study is two-fold: (1) to identify the patterns and commonalities exhibited among the information literacy frameworks formulated in different countries or regions; and (2) to examine how teachers and principals perceive information literacy and its role in the student learning.

To develop a global perspective on and deepen our understanding of the current trend in the development of information literacy, a set of representative information literacy models from different regions were selected for scrutiny. The eight selected models were SUNY (State University of New York, 2002), ACRL (Association of College \& Research Libraries, 2003), AASL (American Association of School Librarians and the Association for Educational Communications and Technology, 1998), SCONUL (Standing Conference of National and University Libraries from the United Kingdom, 2004), AkASL Alaska Association of School Librarians, 2003), WLMA (Washington Library Media Association, 2004), ANZIIL (Australian and New Zealand Institute of Information Literacy, 2004) and JULM (Juarez University Libraries, 2004). Adopting the grounded theory approach (Strauss and Corbin, 1998), the goal of analysis was to identify key features 
Table 1

Demographic data of the survey

\begin{tabular}{ccccc}
\hline Category & $\begin{array}{c}\text { No. of schools } \\
\text { invited }\end{array}$ & $\begin{array}{c}\text { No. of } \\
\text { questionnaires } \\
\text { sent }\end{array}$ & $\begin{array}{c}\text { No. of } \\
\text { questionnaires } \\
\text { returned }\end{array}$ & $\begin{array}{c}\text { Response } \\
\text { rate }(\%)\end{array}$ \\
\hline Total primary schools & 786 & 2358 & 1589 & $67.39 \%$ \\
Total secondary schools & 522 & 1566 & 1019 & $65.07 \%$ \\
\hline Total & 1308 & 3924 & 2608 & $66.46 \%$ \\
\hline
\end{tabular}

commonalities exhibited among the selected IL models. While there were no a priori categories of information literacy standards, the analysis was initiated with open coding. Initially, two researchers in the team generated independently the coding scheme for the information literacy standards. The two researchers then reviewed these two initial coding schemes to arrive at a consensus on the important coding categories that can best reflect the attributes of each IL standard. A new coding scheme was subsequently formulated and used to recode the original set of transcriptions. This exercise of modifying the coding rubric and comparing independent coding results continued until the inter-coder reliability (Cohen's kappa) for the two coders reached 0.8 or above. As a result, a set of categories or a coding scheme of information literacy standards was derived.

On the other hand, to deepen our understanding of teachers' and principals' perceptions on information literacy framework for students in Hong Kong, a questionnaire was developed. The questionnaire was divided into four parts that covered goals, knowledge and attitude, implementation, and expected difficulties. A total of 3924 questionnaires were sent, along with a cover letter that explained the background of the study and the concept of information literacy, to all 1308 primary and secondary schools in Hong Kong in December 2004 to invite the participation of principals, curriculum coordinators, teachers responsible for coordinating IT across the curriculum and teacher librarians. The total number of questionnaires returned was 2608 for a response rate of $66.46 \%$. Table 1 illustrates the demographic data of the survey.

\section{Results and Discussions}

\subsection{Building the Framework for Information Literacy}

For the purpose of initial coding, we propose a working framework comprising four dimensions of learning (see Fig. 1): cognitive, meta-cognitive, affective and socio-cultural. As such, the cognitive dimension addresses the need to enable students to master the necessary information skills to inform decisions and problem solving; the meta-cognitive dimension emphasises on developing students as reflective learners; and the affective dimension addresses the need to enable students to appreciate and enjoy the process of inquiry; and the socio-cultural dimension addresses the need to empower them with greater 


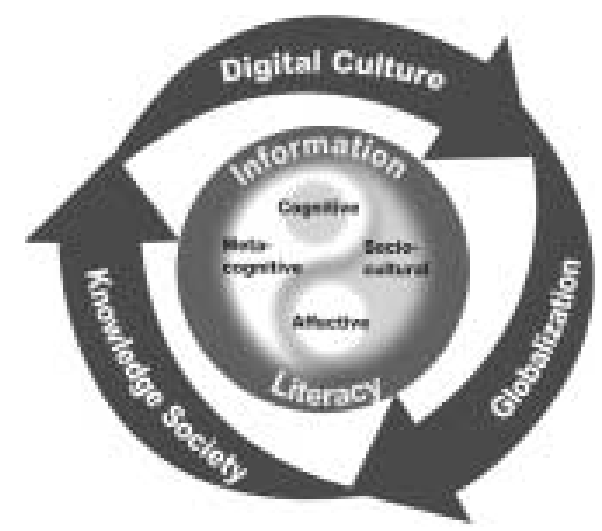

Fig. 1. A conceptual model for Information Literacy.

autonomy and social responsibility over the use of information in their individual as well as collaborative learning. Thus, these four key dimensions of learning provide the theoretical underpinnings for coding and formulation of the entire IL framework.

Despites the variations in scope and coverage exhibited among various models of information literacy, results of the analysis indicated that the IL standards of the eight selected frameworks could readily be classified into the four key dimensions of learning: cognitive, meta-cognitive, affective and socio-cultural dimensions. Table 2 gives a brief illustration of the classification of IL standards of the eight selected frameworks according to the four dimensions of learning. The independent coding rubrics derived by the researchers were constantly compared and modified. A set of coding scheme was finally derived with the inter-coder reliability (Cohen's kappa) reached 0.87 . The coding scheme, as depicted in Fig. 2, represents the commonality exhibited among a variety of

Table 2

Classification of information literacy standards of the eight selected models. The number attached to each label represents the corresponding IL standard of that model

\begin{tabular}{llll}
\hline \multicolumn{1}{c}{ Cognitive } & \multicolumn{1}{c}{ Meta-cognitive } & \multicolumn{1}{c}{ Affective } & \multicolumn{1}{c}{ Socio-cultural } \\
\hline ANZIIL1, ANZIIL2, ANZIIL3, & ANZIIL1, & AkASL3, & ANZIIL6, \\
ANZIIL4, ANZIIL5, WL1, WL2, & ANZIIL2, & AkASL4, AASL4, & AkASL4, \\
WL3, WL4, WL5, WL6, AkASL1, & ANZIIL3, WL4, & AASL5, ACRL3, & AkASL5, UK4, \\
AkASL2, SCONUL1, SCONUL2, & WL6, AkASL4, & SUNY9 & SCONUL6, \\
SCONUL3, SCONUL4, & AASL1, AASL4, & & AASL3, AASL4, \\
SCONUL5, SCONUL6, & AASL5, ACRL1, & & AASL7, AASL8, \\
SCONUL7, AASL1, AASL2, & ACRL2, ACRL3, & AASL9, ACRL4, \\
AASL3, AASL4, AASL5, ACRL1, & ACRL4, SUNY1, & & ACRL5, SUNY3, \\
ACRL2, ACRL3, ACRL4, & SUNY2, SUNY9, & & SUNY7, SUNY8, \\
SUNY1, SUNY2, SUNY3, & JULM4 & & \\
SUNY4, SUNY5, SUNY6, & & \\
SUNY7, JULM1, JULM2, & & \\
JULM3, JULM5, JULM6, JULM7 & & \\
\hline
\end{tabular}




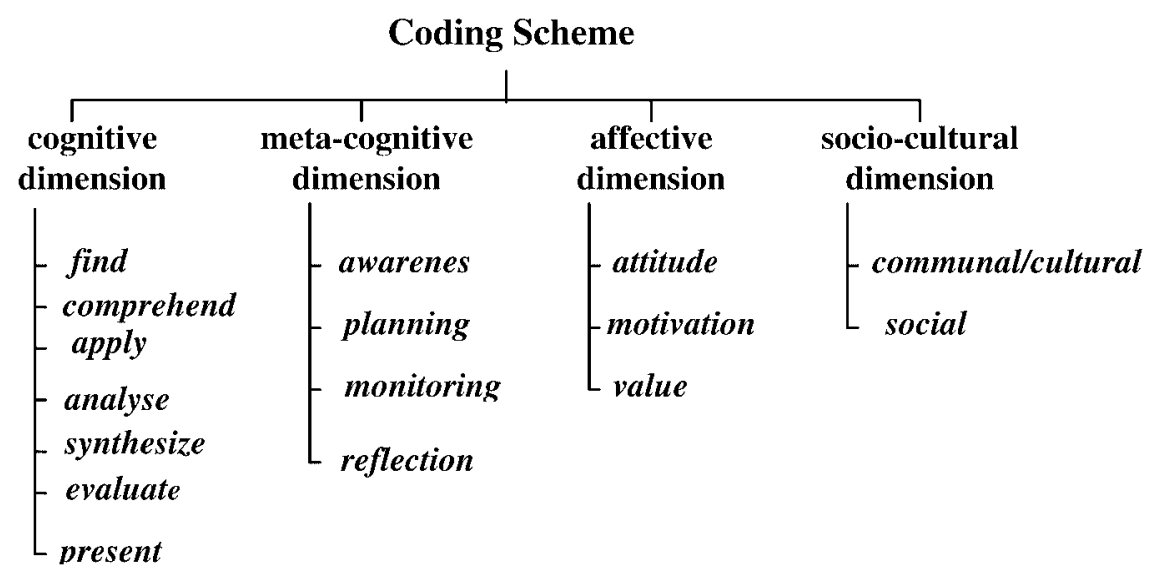

Fig. 2. A coding scheme for analysing the selected models of information literacy.

IL frameworks formulated in different regions of the world, in responding to the quest for developing in students the capacity for lifelong learning and assuming greater autonomy and social responsibility over their learning. The coding scheme thus provides a hierarchical skeleton for framing the IL framework for Hong Kong students.

To embrace all of the aforementioned dimensions of information literacy, eleven standards were formulated. Among those standards, four are in the cognitive dimension, three are in the meta-cognitive dimension, two are in the affective dimension and two are in the socio-cultural dimension. Table 3 provides a summary of the information literacy standards constructed. For each standard, it encompasses a number of indicators that provide detailed descriptions for formulating the corresponding anticipated learning outcomes. Each indicator of the IL standard entails a set of learning outcomes that detail the levels of proficiency in a particular performance area in information literacy. Levels I, II, III and IV indicate respectively the expected IL learning outcomes for students at Junior Primary, Senior Primary, Junior Secondary and Senior Secondary (Kong et al., 2005).

\subsection{Practitioners' Perceptions}

In the questionnaire design, a 4-point Likert scale was adopted with 1: strongly disagree; 2: disagree; 3: agree and 4: strongly agree, to examine teachers and school principals' views on the 32 indicators derived from the 11 standards of the IL framework (Kong et al., 2005). Over $95 \%$ of respondents agreed that information literacy should be infused into curriculum. This shows that the practitioners considered that students being information literate was very important. The average ratings on the indicators regarding the four dimensions of the derived framework show that most practitioners were in agreement on each indicator. To further study the framework in terms of using IT for developing basic abilities in information processing, all participants were asked to rate the indicators of the four dimensions. Tables 4-7 show the average ratings of the cognitive, meta-cognitive, affective and socio-cultural dimensions, respectively. The average ratings of the indicators 
Table 3

Information literacy standards in 4 dimensions: cognitive (C), meta-cognitive (M), affective (A) and sociocultural (S)

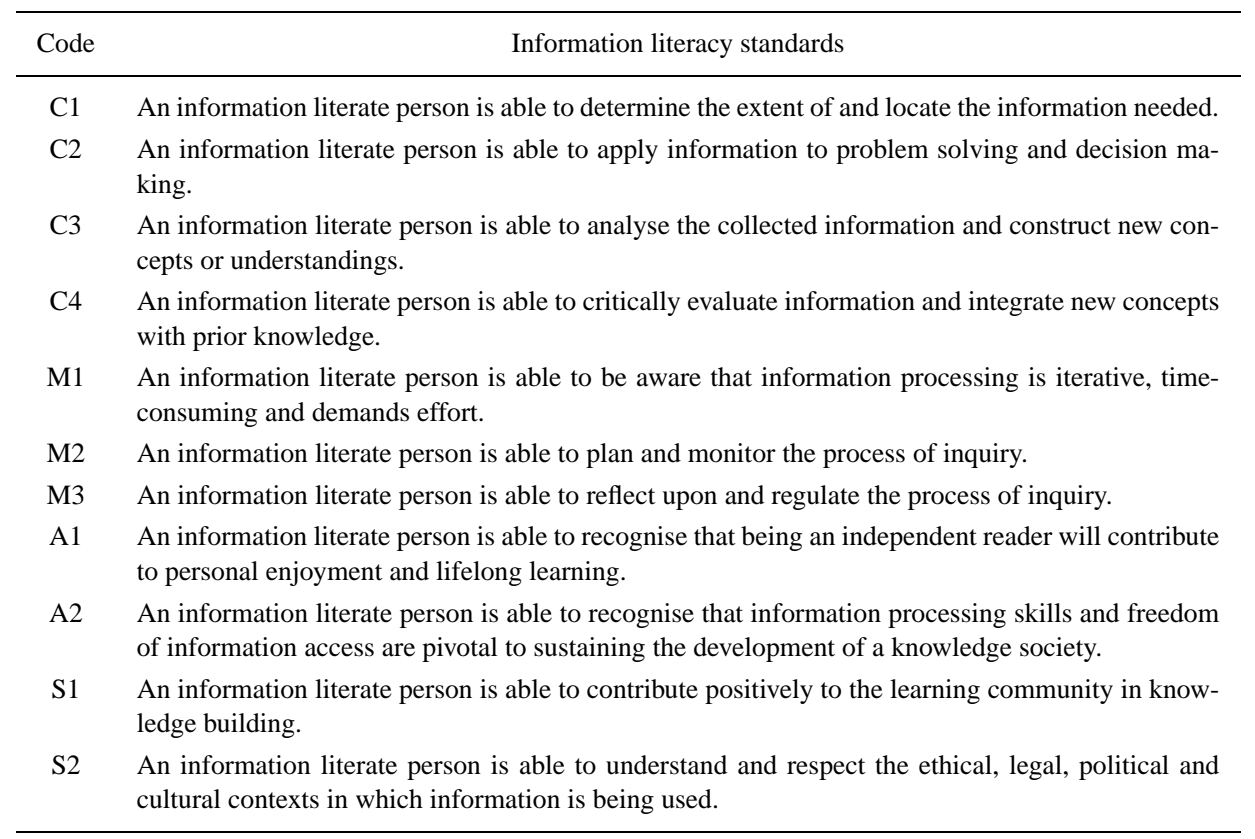

ranged from 3.30 to 3.54 , which indicate that most participants either agreed or strongly agreed with each indicator. The average ratings of the indicators of cognitive dimension ranged from 3.30 to 3.48 , of the meta-cognitive dimension ranged from 3.30 to 3.50 , of the affective dimension ranged from 3.47 to 3.54 and of the socio-cultural dimension ranged from 3.44 to 3.51 . This implies that the standards and indicators formulated were well received by most of the school principals and teachers.

In the average ratings of the expected abilities possessed by primary students after graduation, four indicators in the affective dimension and three indicators in the sociocultural dimension were rated in the 10 most important indicators that should be possessed by primary students when they were graduated. For secondary students, four indicators in the affective dimension and four indicators in the socio-cultural dimension were rated in the 10 most important indicators that they should possess. This illustrates that both the affective and socio-cultural dimensions were believed to be important elements for primary and secondary students.

The difference between the expected abilities possessed by primary and secondary students can be seen from one indicator in the cognitive dimension. When compared to other indicators, primary practitioners did not expect too much from primary students in terms of being able to apply information in problem solving. In contrast, secondary practitioners considered this ability to be vital for secondary students. Primary school participants considered cultivating primary students to read for information and pleasure 
Table 4

Average ratings of the indicators of the cognitive dimension

\begin{tabular}{rlrc}
\hline & \multicolumn{1}{c}{ When students graduate, they are expected to be able to: } & Average (1-4) & S.D. \\
\hline g. & Apply information in problem solving & 3.51 & 0.53 \\
a. & Identify a variety of potential sources of information & 3.48 & 0.52 \\
b. & Develop strategies for locating information & 3.46 & 0.54 \\
e. & Apply information to inform decisions & 3.45 & 0.53 \\
c. & Frame appropriate questions based on information needs & 3.42 & 0.52 \\
f. & Apply information in critical thinking & 3.42 & 0.57 \\
i. $\quad$ Critically analyse information collected & 3.41 & 0.55 \\
l. & Determine the accuracy, relevance and comprehensiveness of information & 3.41 & 0.56 \\
d. & Determine the nature and scope of the information needed & 3.38 & 0.52 \\
m. & Assimilate new concepts into their knowledge bases and value systems & 3.37 & 0.55 \\
h. & Record, categorise and manage the information and its sources & 3.36 & 0.55 \\
k. & Make inferences, connections and draw conclusions & 3.34 & 0.55 \\
j. & Derive new concepts or understandings from the information collected & 3.30 & 0.57 \\
\hline
\end{tabular}

Table 5

Average ratings of the indicators of the meta-cognitive dimension

\begin{tabular}{llr}
\hline \multicolumn{1}{c}{ When students graduate, they are expected to be able to: } & Average (1-4) & S.D. \\
\hline b. $\quad \begin{array}{l}\text { Understand that information processing requires time, diligence and prac- } \\
\text { tice }\end{array}$ & 3.50 & 0.51 \\
a. $\quad \begin{array}{l}\text { Recognise that the information seeking process is evolutionary and changes } \\
\text { during the course of investigation }\end{array}$ & 3.45 & 0.52 \\
e. $\quad \begin{array}{l}\text { Reflect upon the development process of the product/performance and iden- } \\
\text { tify areas of improvement }\end{array}$ & 3.45 \\
c. Define a manageable focus and timeline & 3.42 & 0.55 \\
g. Review the information seeking process and revise search strategies as nec- & 3.37 & 0.56 \\
f. $\quad \begin{array}{l}\text { Devise strategies for revising, improving and updating self-generated } \\
\text { knowledge }\end{array}$ & 3.31 & 0.57 \\
d. Apply new and prior information to the planning and creation of a particular & 3.30 & 0.57 \\
\end{tabular}

as an essential element of information literacy, whereas recognising that being an independent learner will contribute to lifelong learning was regarded to be most significant for secondary students. Tables 8 and 9 present respectively the 10 highest rated abilities expected for primary students and secondary students.

Despite the variation in practitioners' views on the relative importance of the IL standards and indicators, the set of the 10 most important indicators selected by practitioners from both the primary and secondary sectors comprises indicators derived from the cognitive, meta-cognitive, affective and the socio-cultural dimensions of learning. This indi- 
Table 6

Average ratings of the indicators of the affective dimension

\begin{tabular}{llrr}
\hline \multicolumn{1}{c}{ When students graduate, they are expected to be able to: } & Average (1-4) & S.D. \\
\hline d. $\quad \begin{array}{l}\text { Recognise that being an independent learner will contribute to lifelong } \\
\text { learning }\end{array}$ & 3.54 & 0.53 \\
b. $\quad \begin{array}{l}\text { Recognise and select materials appropriate to personal abilities and inter- } \\
\text { ests }\end{array}$ & 3.51 & 0.51 \\
c. Recognise that accurate and comprehensive information is the basis for in- & 3.49 & 0.53 \\
& 3.47 & 0.54 \\
a. $\quad \begin{array}{l}\text { Read for information and pleasure } \\
\text { e. Recognise the importance of freedom of information access to a knowledge }\end{array}$ & 3.47 & 0.53 \\
\end{tabular}

Table 7

Average ratings of the indicators of the socio-cultural dimension

\begin{tabular}{clcc}
\hline & \multicolumn{1}{c}{ When students graduate, they are expected to be able to: } & Average (1-4) & S.D. \\
\hline e. & Understand and respect for the principle of intellectual freedom & 3.51 & 0.53 \\
b. $\quad$ Collaborate effectively in groups to pursue and construct knowledge & 3.48 & 0.54 \\
d. $\quad$ Understand and respect the principles of equitable access to information & 3.48 & 0.53 \\
a. $\quad$ Share knowledge and information with others & 3.45 & 0.52 \\
c. Recognise that information is underpinned by values and beliefs & 3.44 & 0.54 \\
f. $\quad$ Observe laws, institutional policies and social etiquette related to access to & 3.44 & 0.53 \\
& and the use of information & &
\end{tabular}

Table 8

The 10 highest ratings by primary school practitioners of the abilities expected to be possessed by primary students

\begin{tabular}{|c|c|c|c|}
\hline Code & When students graduate, they are expected to be able to: & Average (1-4) & S.D. \\
\hline A & a. Read for information and pleasure & 3.36 & 0.52 \\
\hline M & $\begin{array}{l}\text { b. Understand that information processing requires time, diligence and } \\
\text { practice }\end{array}$ & 3.33 & 0.50 \\
\hline A & $\begin{array}{l}\text { b. Recognise and select materials appropriate to personal abilities and in- } \\
\text { terests }\end{array}$ & 3.32 & 0.52 \\
\hline S & a. Share knowledge and information with others & 3.27 & 0.48 \\
\hline $\mathrm{S}$ & e. Understand and respect the principle of intellectual freedom & 3.27 & 0.55 \\
\hline $\mathrm{S}$ & b. Collaborate effectively in groups to pursue and construct knowledge & 3.25 & 0.54 \\
\hline S & d. Understand and respect the principles of equitable access to information & 3.24 & 0.54 \\
\hline M & $\begin{array}{l}\text { a. Recognise that the information seeking process is evolutionary and } \\
\text { changes during the course of investigation }\end{array}$ & 3.22 & 0.50 \\
\hline $\mathrm{C}$ & g. Apply information in problem solving & 3.22 & 0.54 \\
\hline A & $\begin{array}{l}\text { d. Recognise that being an independent learner will contribute to lifelong } \\
\text { learning }\end{array}$ & 3.19 & 0.64 \\
\hline
\end{tabular}


Table 9

The 10 highest ratings by secondary school practitioners of the abilities expected to be possessed by secondary students

\begin{tabular}{lllll}
\hline Code & \multicolumn{1}{c}{ When students graduate, they are expected to be able to: } & Average (1-4) & S.D. \\
\hline A & d. & $\begin{array}{l}\text { Recognise that being an independent learner will contribute to lifelong } \\
\text { learning }\end{array}$ & 3.49 & 0.53 \\
A & b. & $\begin{array}{l}\text { Recognise and select materials appropriate to personal abilities and in- } \\
\text { terests }\end{array}$ & 3.45 & 0.51 \\
C & g. & Apply information in problem solving & 3.45 & 0.53 \\
S & e. & Understand and respect the principle of intellectual freedom & 3.45 & 0.53 \\
A & c. & Recognise that accurate and comprehensive information is the basis for & 3.44 & 0.54 \\
M & b. & Understand that information processing requires time, diligence and & 3.44 & 0.51 \\
S & d. & Understand and respect the principles of equitable access to information & 3.41 & 0.54 \\
A & a. & Read for information and pleasure & 3.40 & 0.54 \\
S & f. & Observe laws, institutional policies and social etiquette related to access & 3.40 & 0.53 \\
S & b. & Collaborate effectively in groups to pursue and construct knowledge & 3.40 & 0.55 \\
\hline
\end{tabular}

cates that the traditional way of conceptualizing information literacy solely as a kind of cognitive skills is seen to be inadequate to address the learning needs in the 21 st century. Through the process of interacting with information, students may undergo a multitude of learning experience. In curriculum design, it is therefore desirable to adopt a spiral approach to developing students' information literacy so that at each level of their schooling they are able to have the learning experience stipulated in the four dimensions of learning.

\section{Conclusion}

Information literacy is the mastery of the processes of becoming informed. It is considered to be crucial for people to cope with the rapid changes in the information age, driven by the emerging digital culture, globalisation and the development of a knowledge-based society. These changes have necessitated the infusing of information literacy into the school curriculum and thus the development of an information literacy framework for students. The development of such a framework should therefore enable students to master the skills that are necessary for information processing, instil in them the ability to reflect on and regulate their learning, enable them to appreciate that being independent learners will contribute to personal growth, enjoyment and lifelong learning, and empower them with greater autonomy and social responsibility over the use of information in their individual and collaborative learning.

The information literacy framework should encompass the learning outcomes derived in the four dimensions of learning: cognitive, meta-cognitive, affective and socio-cultural. The research findings showed that the standards and indicators established were recog- 
nized. Over $95 \%$ of the respondents agreed that information literacy education is needed for students in Hong Kong. The average ratings of the indicators (sets of expected characteristics that were developed based on information literacy standards) ranged from 3.30 to 3.54 on a 4-point scale, which shows that they were well received. Results of this study indicate that the traditional notion of information literacy is inadequate to address the learning needs in the 21 st century and a spiral approach to developing students' information literacy is deemed necessary.

\section{References}

Alaska Association of School Librarians (2003). Library and Information Literacy Standards. Retrieved 28 January 2005, from

http: //www.akla.org/akasl/lib/studentstandards.html.

American Association of School Librarians and the Association for Educational Communications and Technology (1998). Information Literacy Standards for Student Learning. Retrieved 28 January 2005, from http: //www.ala.org/ala/aasl/aaslproftools/informationpower/Information Literacystandards_final.pdf.

Association of College \& Research Libraries (2003). Information Literacy Standards Toolkit. Retrieved 28 January 2005, from

http://www.ala.org/ala/acrl/acrlissues/acrlinfolit/infolitstandards/ standardstoolkit.htm.

Australian and New Zealand Institute of Information Literacy (2004). Australian and New Zealand Information Literacy Framework: Principles, Standards and Practice. Retrieved 28 January 2005, from

http://www.anzil.org/resources/Info\%20lit $\% 202$ nd\%20edition.pdf.

Bates, A.W. (2000) Management Technology Change. Strategies for College and University Leaders. JosseyBass, San Francisco.

Curriculum Development Council (2000). Information Technology Learning Targets. Curriculum Development Council, Hong Kong.

Education and Manpower Bureau (1998). Information Technology for Learning in a New Era Five-Year Strategy 1998/99-2002/03. Education and Manpower Bureau, Hong Kong.

Education and Manpower Bureau (2004). Empowering Learning and Teaching with Information Technology. Education and Manpower Bureau, Hong Kong.

Education and Manpower Bureau (2005). Overall Study on Reviewing the Progress and Evaluating the Information Technology in Education (ITEd) Projects 1998-2003. Education and Manpower Bureau, Hong Kong.

Juarez University Libraries (2004). Information Literacy Standards. Retrieved 28 January 2005, from http://bivir.uacj.mx/bibliotecas/.

Kong, S.C., F.L Lee, J. Henri, and S.C. Li (2005). Report on Information Literacy Framework for Hong Kong Students. Education and Manpower Bureau, Hong Kong Special Administrative Region Government (unpublished).

Henri, J. (1995). The information literate school community: Exploring a fuzzy concept. Scan, 14(3), 25-28.

Menou, M. (2002). Information literacy in national information and communications technology (ICT) policies: The missed dimension, information culture. In White Paper prepared for UNESCO, the U.S. National Commission on Libraries and Information Science, and the National Forum on Information Literacy, for use at the Information Literacy Meeting of Experts, Prague, The Czech Republic. Retrieved January 20, 2005, from http://www.nclis.gov/libinter/infolitconf\&meet/papers/menoufullpaper.pdf.

O'Sullivan, C. (2002). Is information literacy relevant in the real world? Services Review, 30(1), 7-15.

Sanford, S. (2000). Terry Crane: Inspiring connections. Retrieved February 24, 2005 from http://www. centerdigitaled.com/converge/?pg=magstory\&id=3374

Standing Conference of National and University Libraries from the United Kingdom (2004). Learning Outcomes and Information Literacy. Retrieved 28 January 2005, from http://www.sconul.ac.uk/activities/inf_lit/papers/outcomes.pdf. 
State University of New York (2002). Information Literacy Learning Outcomes for SUNY Oswego Undergraduate. Retrieved 28 January 2005

http://www.oswego.edu/library/instruction/outcomes.pdf.

Strauss, A.L., and J. Corbin (1998). Basics of Qualitative Research: Techniques and Procedures for Developing Grounded Theory. Sage Publications, Thousand Oaks.

Washington Library Media Association (2004). Information Literac. Retrieved 28 January 2005, from http://www.wlma.org/Instruction/infolit.htm

World Summit on the Information Society (2003). Building the Information Society: a Global Challenge in the New Millennium. Retrieved 28 January 2005, from

http://www.itu.int/dms_pub/itu-s/md/03/wsis/doc/WSIS-DOC-0004PDF-E.pdf.

S.C. Li received a BSc (hons) in 1984 from the University of Hong Kong and postgraduate certificate in education in subsequent years from the same university. He received his $\mathrm{PhD}$ in theoretical nuclear and particle physics in 1996 from the Australian National University. He was a secondary school teacher in Hong Kong for eight years before pursuing his $\mathrm{PhD}$ degree. He was a postdoctoral research fellow in ANU, working in the area of computer simulation and modelling of protein dynamics. He subsequently joined the Centre for Information Technology in Education of the Faculty of Education of the University of Hong Kong as the deputy director from 1998-2001. He is currently an associate professor and also the course coordinator of the full-time postgraduate diploma in education programme at Hong Kong Baptist University. He has been the principal investigator of a number of research projects in the area of IT in education, funded by the Competitive Earmarked Research Grant Committee and the HKSAR government. His articles on computer modelling and IT in education have appeared in many international journals.

S.C. Kong is an assistant professor at the Department of Mathematics, Science, Social Sciences and Technology of the Hong Kong Institute of Education. Dr. Kong is also programme coordinator of the bachelor of education (primary) program. His research and teaching expertise is in information technology in education and mathematics education. $\mathrm{He}$ is a member of the Asia-Pacific Society for Computers in Education, and received the best paper award in 2005 from the Global Chinese Society for Computers in Education. He is currently a member of the Steering Committee on the Strategic Development of Information Technology in Education that was set up by the Quality Education Division of the Education and Manpower Bureau of the Government of the Hong Kong SAR, and is also a member of the Advisory Board of the Centre for the Advancement of Information Technology in Education of the Hong Kong Institute of Educational Research, which is part of the Chinese University of Hong Kong. Dr. Kong received a bachelor of science (honors) in mathematics, a postgraduate diploma in education with distinction in coursework, and a master of arts in education from the Chinese University of Hong Kong. In addition, he gained a master of science in computing with distinction and a doctor of philosophy from the Department of Computer Science of the City University of Hong Kong. Dr. Kong was formerly a senior graduate master of mathematics and computer science at a secondary school, where he also served as chairman of the mathematics and computer studies panel and coordinator of the School Administration Computerization Committee. 
F.L. Lee is an associate professor at the Department of Curriculum and Instsruction of the Chinese University of Hong Kong. Prof. Lee is currently a director of the Centre for Advancement of Information Technology in Education (CAITE) of the Chinese University of Hong Kong, co-chief editor of Journal of Computers in Education for the Global Chinese Community, member of executive committee and chair of publicity subcommittee of the Asia Chapter of Association for the Advancement of Computers in Education, chair of the HK-Macau Chapter of Global Chinese Association for Computers in Education, co-chief editor of Global Chinese Journal on Computers in Education, president of Asia-Pacific Society for Computers in Education, member of the steering committee on the strategic development of information technology in education that was set up by the Quality Education Division of the Education and Manpower Bureau of the Government of the HKSAR and the vice-president of Hong Kong Association for Educational Communication and Technology. Prof. Lee received a bachelor of science (honors) in mathematics, a postgraduate diploma in education, a master of arts in education and a $\mathrm{PhD}$ degree in education from the Chinese University of Hong Kong. Professor Lee formerly served as a secondary school teacher, extra-curricular activities master and chair of the mathematics subject panel. Serving as the principal investigator of a large number of projects, prof. Lee has been very active in reaserch related to IT in education.

J. Henri is an associate professor at the Faculty of Education of the University of Hong Kong. Mr. Henri took up the appointment at the University of Hong Kong in August 2001. Prior to that He spent 20 years at Charles Sturt University in Wagga Wagga, in the Australian State of New South Wales. His current appointment provides him the opportunity to develop programs and courses in Library and Information Science within the Faculty of Education. He is a senior program director of the School of Professional and Continuing Education. Mr. Henri received a bachelor of economics, master of education from Univeristy of Tasmania. Mr. Henri's specialist interest is in teacher librarianship. 


\title{
Mokymosi visa gyvenimą stiprinimas: informacinio raštingumo struktūros tyrimas remiantis praktikuotoju patirtimi
}

\author{
Sandy C. LI, Siu Cheung KONG, Fong Lok LEE, James HENRI
}

Informacinis raštingumas per pastaruosius pora dešimtmečiu smarkiai prisidejjo prie studiju paplitimo. Informacinis raštingumas laikomas lemiamu veiksniu siekiant tiek asmeninès sèkmès, tiek visuomenès ekonominès plètros. Dauguma šiuolaikinių informacinio raštingumo interpretaciju yra neatskiriamai susiję su mokymosi visą gyvenimą koncepcija. Straipsnyje nagrinėjami informacinio raštingumo koncepciju, sukurtu ịvairiose pasaulio vietose, bendrumai. Taip pat nagrinejjamas mokyklų vadovybės ir mokytojų turimi vaizdiniai apie informacinio raštingumo koncepciją ir jos reikšmę mokymuisi. Tyrimo rezultatai rodo, jog internetinio raštingumo praktikuotojų nuomone, informacinis raštingumas turètu apimti keturias mokymosi dimensijas: kognityvinę, metakognityvinę, emocinę ir sociokultūrinę. Šio tyrimo rezultatai parodo, jog tradicinė informacinio raštingumo samprata nebeatitinka XXI amžiaus mokymosi poreikiu. Prieinama prie nuomonès, jog ugdant studentu informacinị raštingumą būtina vadovautis spiraliniu požiūriu. 